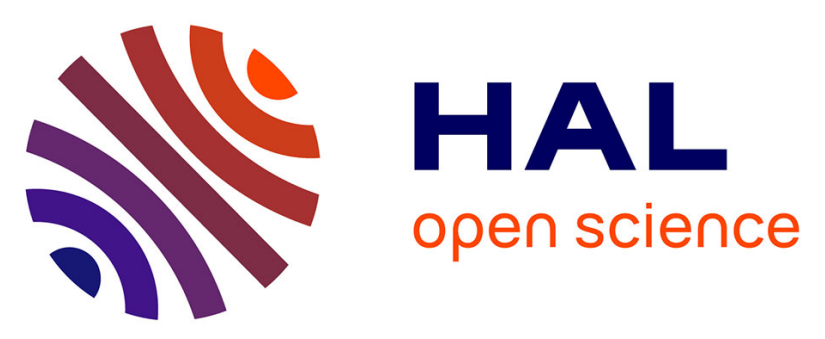

\title{
Social and Hydrological Responses to Extreme Precipitations: An Interdisciplinary Strategy for Postflood Investigation
}

Isabelle Ruin, Céline Lutoff, Brice Boudevillain, Jean-Dominique Creutin, S Anquetin, Marc Bertran Rojo, L Boissier, G Delrieu, E Gruntfest, M Borga, et al.

\section{To cite this version:}

Isabelle Ruin, Céline Lutoff, Brice Boudevillain, Jean-Dominique Creutin, S Anquetin, et al.. Social and Hydrological Responses to Extreme Precipitations: An Interdisciplinary Strategy for Postflood Investigation. Weather, Climate, and Society, 2014, 6 (1), pp.135-153. 10.1175/WCAS-D-13-00009.1 . hal-01083979

\section{HAL Id: hal-01083979 https://hal.science/hal-01083979}

Submitted on 18 Nov 2014

HAL is a multi-disciplinary open access archive for the deposit and dissemination of scientific research documents, whether they are published or not. The documents may come from teaching and research institutions in France or abroad, or from public or private research centers.
L'archive ouverte pluridisciplinaire HAL, est destinée au dépôt et à la diffusion de documents scientifiques de niveau recherche, publiés ou non, émanant des établissements d'enseignement et de recherche français ou étrangers, des laboratoires publics ou privés. 


\title{
Social and Hydrological Responses to Extreme Precipitations: An Interdisciplinary Strategy for Postflood Investigation
}

\author{
Isabelle Ruin, ${ }^{*}$ Céline LutofF, ${ }^{+}$Brice Boudevillain,* JeAn-Dominique Creutin,*

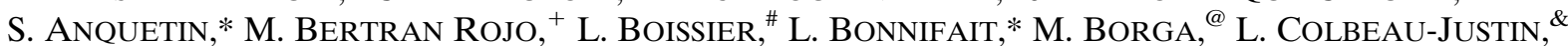 \\ L. Creton-Cazanave, ${ }^{+}$G. Delrieu, ${ }^{*}$ J. Douvinet, ${ }^{* *}$ E. Gaume, ${ }^{++}$E. Gruntfest, ${ }^{\#}$ \\ J.-P. NAUlin, ${ }^{++}$O. PAYRASTRE, ${ }^{++}$AND O. VANNIER $*$ \\ * Laboratoire d'Etude des Transferts en Hydrologie et Environnement, CNRS/UJF, IRD, Grenoble, France \\ ${ }^{+}$UMR PACTE/UJF, Grenoble, France \\ \# Department of Geography, University of Montpellier III, Montpellier, France \\ ${ }^{\circledR}$ Department of Land and Agroforest Environment, University of Padova, Padua, Italy \\ ${ }^{\&}$ Laboratory of Social Psychology, University of Nimes, Nimes, France \\ ** UMR Espace, University of Avignon, Avignon, France \\ ${ }^{++}$IFSTTAR, Nantes, France \\ \#\# University of Colorado Colorado Springs, Colorado Springs, Colorado, and Laboratoire d'Etude des Transferts en \\ Hydrologie et Environnement, CNRS/UJF, IRD, Grenoble, France
}

(Manuscript received 23 January 2013, in final form 8 June 2013)

\section{ABSTRACT}

\begin{abstract}
This paper describes and illustrates a methodology to conduct postflood investigations based on interdisciplinary collaboration between social and physical scientists. The method, designed to explore the link between crisis behavioral response and hydrometeorological dynamics, aims at understanding the spatial and temporal capacities and constraints on human behaviors in fast-evolving hydrometeorological conditions. It builds on methods coming from both geosciences and transportations studies to complement existing postflood field investigation methodology used by hydrometeorologists. The authors propose an interview framework, structured around a chronological guideline to allow people who experienced the flood firsthand to tell the stories of the circumstances in which their activities were affected during the flash flood.

This paper applies the data collection method to the case of the 15 June 2010 flash flood event that killed 26 people in the Draguignan area (Var, France). As a first step, based on the collected narratives, an abductive approach allowed the identification of the possible factors influencing individual responses to flash floods. As a second step, behavioral responses were classified into categories of activities based on the respondents' narratives. Then, aspatial and temporal analysis of the sequences made of the categories of action to contextualize the set of coping responses with respect to local hydrometeorological conditions is proposed. During this event, the respondents mostly follow the pace of change in their local environmental conditions as the flash flood occurs, official flood anticipation being rather limited and based on a large-scale weather watch. Therefore, contextual factors appear as strongly influencing the individual's ability to cope with the event in such a situation.
\end{abstract}

\section{Introduction}

Western Mediterranean regions are favored locations for heavy precipitating events. In recent years, many of them resulted in destructive floods with extended damage and loss of life, including flash floods in France in Nîmes in 1988, Vaison-la-Romaine in 1992, the Aude in

Corresponding author address: Isabelle Ruin, LTHE, Bâtiment OSUG-B, Domaine Universitaire, B.P. 53, 38041 Grenoble CEDEX 09, France.

E-mail: isabelle.ruin@ujf-grenoble.fr
1999, and the Gard in 2002 and 2005 (Delrieu et al. 2005; Gaume et al. 2004). On 15-16 June 2010, the vicinity of the town of Draguignan (Fig. 1), located in the Var department, ${ }^{1}$ was hit by a violent storm. The daily accumulated rainfall reached 200 and $300 \mathrm{~mm}$ over, respectively, 2000 and $250 \mathrm{~km}^{2}$ and led to significant flash flooding (Rouzeau et al. 2010). According to the latter

\footnotetext{
${ }^{1}$ Administrative division of France between the region and the commune, equivalent to 3 to 4 times the median land area of a U.S. county.
}

DOI: 10.1175/WCAS-D-13-00009.1 


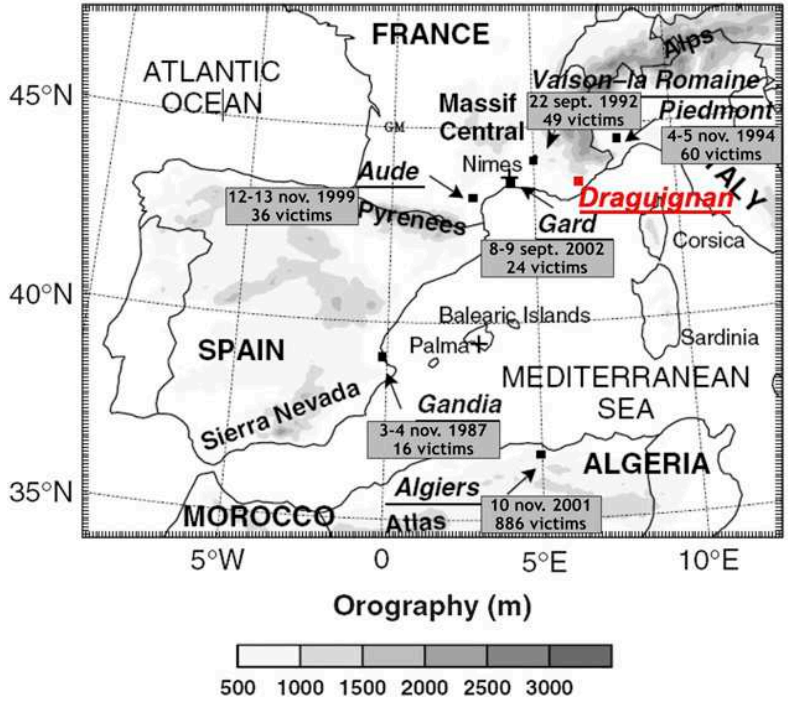

FIG. 1. Location of the city of Draguignan within the Mediterranean area and together with other major historic flash flood events. Annotated from Nuissier et al. (2008).

authors, this event is one of the 20 most important flash flood events reported since the 1950s in the western part of the French Mediterranean coast. Since the last destructive flood occurred in Draguignan in 1827, there was no contemporary memory of that event.

The rainfall event of 15 June 2010 was particularly intense (Fig. 2). The maximum rain amount recorded at the Météo-France station of "Les Arcs-sur-Argens" reached $400 \mathrm{~mm}$ in $24 \mathrm{~h}$ (including $330 \mathrm{~mm}$ in less than $10 \mathrm{~h}$ ) (Fig. 3). These values largely exceed a return period of 100 years (Martin 2010). Two periods of the 2010 event can be seen. During the first period, the atmospheric flux came from south-southwest and led to intense precipitation, but it quickly swept nearly the entire Var department [up to 1600 local time (LT)]. ${ }^{2}$ During the second period, the flow was oriented southeast and precipitation stayed quasi stationary over the Nartuby watershed upstream of Draguignan ( $184 \mathrm{~km}^{2}$ ) (after $\left.1600 \mathrm{LT}\right)$.

The predictability of such phenomena remains low in terms of rainfall intensity and location. In this case study, the rivers responsible for the inundation were not part of the operational river monitoring system managed by the regional flood warning service [Service de Prévision des Crues Méditerranée Est (SPC-ME)]. This is partly because flood forecasting of such quick

\footnotetext{
${ }^{2}$ We choose to express dates in local time $(\mathrm{UT}+2 \mathrm{~h})$ instead of UTC time to be consistent with the rest of the paper in which dates refer to social activities.
}

response catchments remains a scientific challenge. Therefore, only the Météo France vigilance map was available to warn the inhabitants of the department for heavy rainfall and potential flooding. Based on the rainfall forecast, Météo France broadcasted the heavy rainfall watch (Météo-France orange vigilance, third level of warning over a maximum of four) on Monday 14 June at 2300. The 24-h forecast predicted daily rain amount from 80 to $150 \mathrm{~mm}$ for the day of the storm (with a max of about $250 \mathrm{~mm}$ ). The orange vigilance warning launched the day before concerned 11 French departments (i.e., $\left.60000 \mathrm{~km}^{2}\right)$ and then 6 departments $\left(32000 \mathrm{~km}^{2}\right)$ on the morning of the storm day. The warning level that is issued when the daily forecasted precipitation is greater than $200 \mathrm{~mm}$ was never reached so the red vigilance was not issued.

This event was responsible for the death of 26 people and damages were evaluated at 1 billion euros. A number of 2450 persons were rescued, including 1350 who were airlifted and 300 who escaped very perilous situations (Rouzeau et al. 2010). Three municipalities experienced most of the fatal accidents: Draguignan (10), Trans-enProvence (Trans) (5), and Roquebrune (5). As often in case of flash flooding, the circumstances of the accidents are nearly evenly distributed into two categories: on the one hand, casualties happening inside buildings (13 cases over 26) and mostly affecting elderly (average age $=$ 68 ; median age $=79$ ), and on the other hand, casualties occurring on the road when walking or driving (13 out of 26 ) and affecting younger people (average age $=52$; median age $=56$ ), especially males (nine men and four women) (Vinet et al. 2012). The way age and circumstances were distributed has already been observed for the 2002 flash flood event in the Gard region in France (Ruin et al. 2008). This paper also indicates a possible link between the accidents' circumstances, the age of the victims, and the flood dynamics related to the scale of the upstream drainage area.

Even with such a heavy death toll, the consequences could have been even more dramatic considering the violence of the floods, the lack of flood alerts, and the significant damage in the vicinity of Draguignan. Actually, the timing of the flood corresponds to rush hour for most of the municipalities. In the small surrounding village of Figanières, for instance, the residents felt lucky that the peak flow in the main street happened 15 min after schools dismissed their students for the day.

This flash flood event offers a typical example to study the relation between the flood dynamics and the dynamic of the social response. Flash floods differ from slow rise riverine floods. With flash floods, the time of peak flows in the different rivers across the storm area may vary greatly according to the structure and motion 


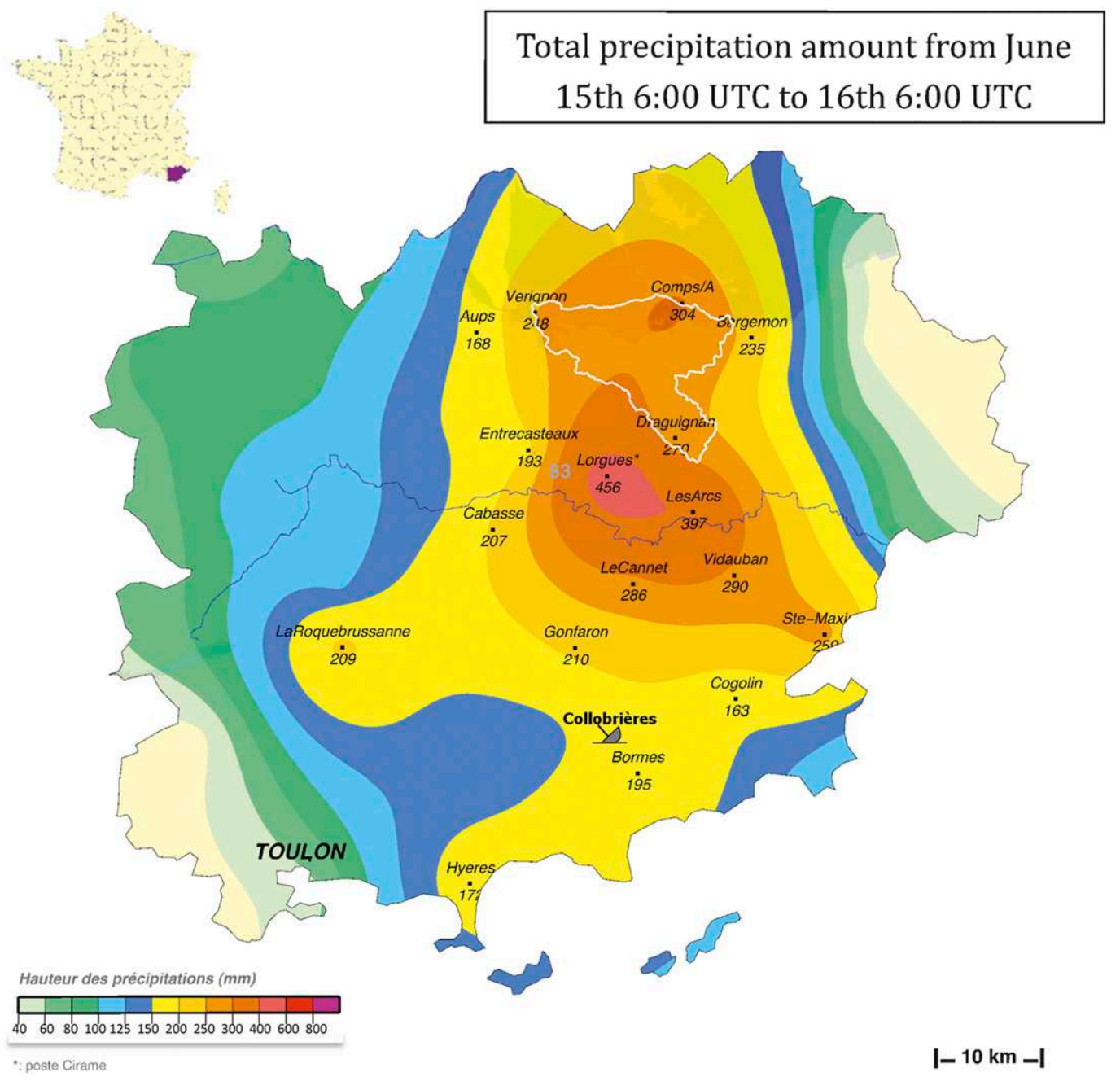

FIG. 2. Total precipitation amount from 0600 UTC 15 Jun 2010 to 0600 UTC 16 Jun 2010. (From Météo-France http://pluiesextremes.meteo.fr August 2011 edition.)

of the convective storm (more than propagation in rivers). This asynchronicity of peak flows seems to be a significant source of danger (Creutin et al. 2013). It forces crisis managers and/or individuals to adapt to the rapid evolution of local conditions in a way different from standard emergency response to riverine floods. In the case of the storm of 15 June 2010 (that we call the Draguignan case hereafter) the rapidity of the river rise and the lack of anticipation of the authorities compelled many individuals and communities to organize themselves to cope locally with the event. The flood happened so quickly that some communities did not have time to even access rescue services. Nevertheless, individuals and improvised groups managed to inform, organize, and protect themselves on their own, without any official involvement (Parker and Handmer 1998; Creutin et al. 2009). Investigating human and environmental circumstances of personal stories experienced by individuals and groups in such a crisis is key to learning more about the link between environmental conditions and social settings. To better learn from those positive cases and to consider the influence of environmental conditions versus social settings, we need to investigate the various circumstances of such successful adaptation. Why and when did people change their behaviors when faced with the quickly changing environmental conditions?

This paper describes and illustrates a new methodology to conduct postevent field investigations based on interdisciplinary collaboration between social and physical scientists. Past experience shows that postflood investigation methodologies have been developed for diverse purposes. For example, local and national authorities conduct such legal/administrative investigations to officially answer public concerns about the cause and 


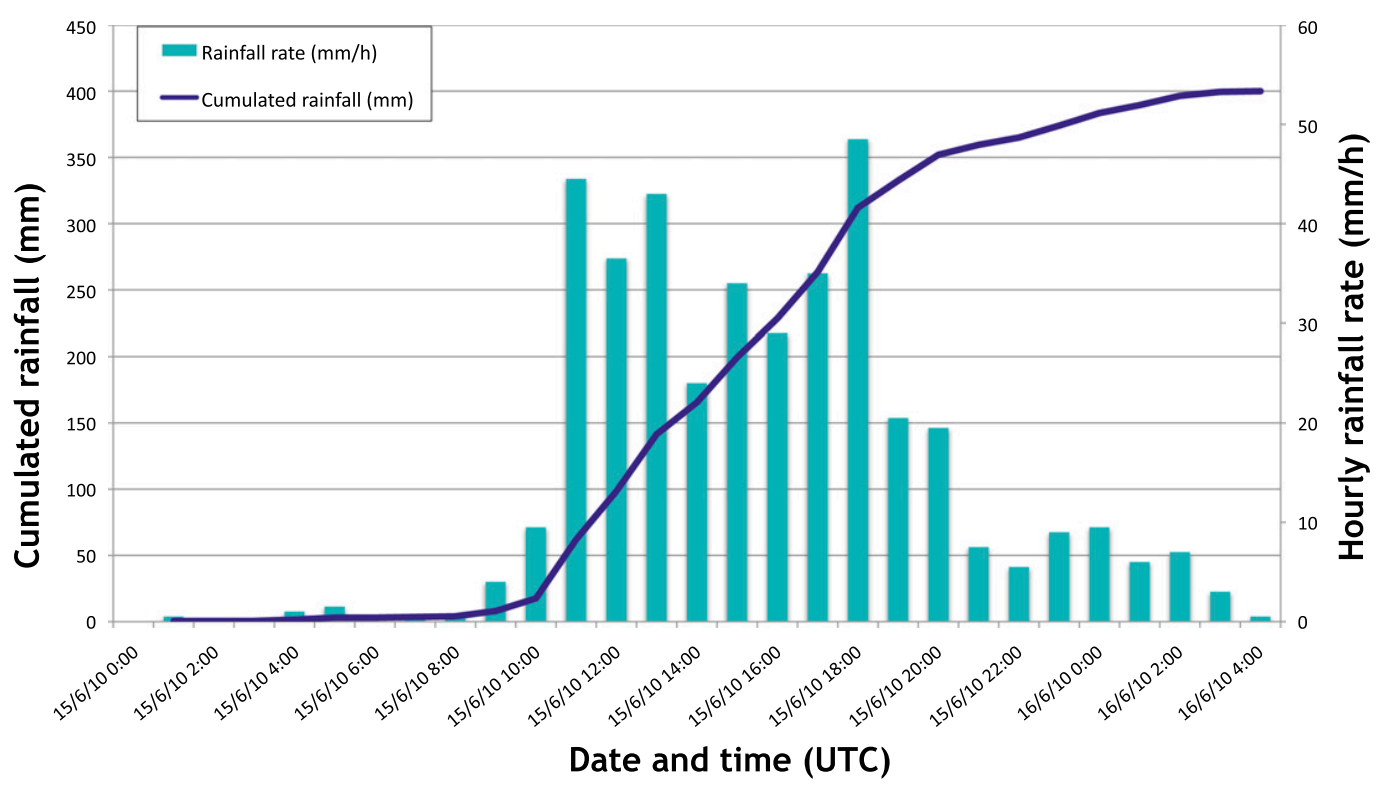

FIG. 3. Hyetograph at the Météo-France station of Les Arcs-sur-Argens.

impacts of floods (Lefrou et al. 2000; Huet et al. 2003; Hornus and Martin 2005; Rouzeau et al. 2010). Operational services, like the U.S. Geological Survey or the National Weather Service, conduct "service assessments." Research institutions also investigate extreme events after they occur (Gaume et al. 2004; Delrieu et al. 2005; Gaume and Borga 2008; Martin 2010; Payrastre et al. 2012). However, postflood collaborations between social and physical scientists remain rare. The few examples of multidisciplinary work, when examined closely, are not integrated collaborative projects but patchwork quilts of a variety of specialists who study separate aspects of an event. In this flood study arena, true integration of information, data, and knowledge from different fields is lacking, with the result that neither the physical nor the social science perspectives gain a comprehensive picture of the extreme event. This paper attempts to demonstrate that integration of physical and social concerns under the form of common research questions and methodology is possible and useful.

This paper is organized into five sections. Section 2 explains the interdisciplinary research questions, purpose, and theoretical background. Section 3 investigates the possible causes of individual responses based on the analysis of the narratives. Section 4 shows the preliminary results of the analysis based on a space-time framework pertinent to compare the dynamics of both the natural phenomena and the social response. Finally, the conclusions and implications for future research are reported in section 5 .

\section{Purpose and theoretical background}

\section{a. Contextual factors: A key question to understand individual responses}

Postevent investigations of the 2007 floods in England (Pitt 2008), Xynthia (Leonard 2010), and flash flooding in the Var region (Rouzeau et al. 2010) in France highlighted serious breakdowns in the warning response system. Nevertheless, the literature on the factors influencing individual and societal responses to such early warnings remains weak (Mileti 1995; Drabek 1986, 2000; Sorensen 2000; Parker et al. 2009). Lindell and Perry (1992, 2004) developed a Protective Action Decision Model (PADM) of residents' responses to hurricane warnings as a composite of new information and environmental cues combined with preexisting beliefs based on past experience. Their model of agent response helpfully incorporates the temporal dimension in terms of individual experience, forecast lead time, and the time required for evacuation and other protective action. Nevertheless, it is aspatial and ignores contextual factors such as neighborhood effects on individual responsiveness (Parker and Handmer 1998) as well as the potential for emergent effects. However, other works have highlighted the importance of these contextual factors, such as the timing of an event (i.e., middle of the night vs midday) within the rhythms of everyday life (Ruin 2010), as key influences on individual and institutional responses to warnings. These individual and institutional responses are defined as multiscalar and nonlinear and involve what has been called "socially distributed cognition" (Dash and Gladwin 
2007) in which, as the FLOODsite project concluded, "context is everything in understanding flood warning response" (Parker et al. 2009, p. 104).

Thus, based on several studies performed in Europe concerning social responses to flooding, Parker et al. define two categories of contextual factors influencing the responses to flood warning: physical characteristics and social circumstances (Parker et al. 2009). Among physical characteristics, the severity of the flood and the time available between the warning and the flood appear as the most important factors on social responses. Concerning social characteristics, people's experience, their knowledge concerning flood risk, and the distribution of responsibility for responding to flooding are identified as the main influencing factors for floods.

Because of the suddenness in the rise of water levels and the spatial dispersion of the possible impacts, timely flash floods warning (official warning) is limited and insufficient (Borga et al. 2011). Flash floods often surprise people in the midst of their daily activity and force them to react in a very limited amount of time. In such fast evolving events, impacts depend not just on such compositional variables as the magnitude of the flood event and the vulnerability of those affected, but also on such contextual factors as its location and timing. Depending on contingent conditions (e.g., at night when it is difficult to see, rush hours when there are errands to run and children to pick up and lots of other cars on the road, or working hours when people feel they must be at work regardless of the conditions), perception of environmental cues needed for self-warning may be hindered. Likewise, the nature and dynamics of the individuals' reactions will differ according to the location and activity they were performing when they felt the need for action as well as their capability to connect with their relatives or to have social interactions allowing a group response (Gruntfest 1977; Mileti 1995; Drabek 2000; Lindell and Perry 2004). Those specific contextual factors can alter the scale and social distribution of impacts and vulnerability to them. In the case of flooding fatalities, for instance, the elderly are often said to be the most vulnerable (Parker et al. 2009), but when fatalities are mapped against basin size and response time, it has been shown that in fact it is young adults who are most likely to be killed in flash flooding of small catchments, whereas the elderly are the most frequent victim of large-scale fluvial flooding (Ruin et al. 2008).

Further investigations in the Gard region in France, where social response to flash flood was examined in detail, have shown that such a tendency could be explained by a difference of attitude across ages with respect to mobility related to daily life routine and constraints (Ruin 2010). Even if this appears as a tendency in both the analysis of limited data on death circumstances and intended behavior surveys, behavioral verification is very much needed.

Collecting data on actual behavioral responses or practices in the context of hardly predictable extreme weather events is a challenging problem. Participant observations are not possible for evident reasons. Indirect observations using sensors or videos pose questions of the quantity and spatial distribution of the observation devices, the quality and completeness of the data they provide, and their robustness in extreme conditions. Even for hydrological purposes, such devices are often overwhelmed and/or unreliable in flash flooding conditions (Gaume and Borga 2008). The observation and understanding of individual behaviors requires more qualitative methods, already broadly used when studying the interactions between society and the environment in the context of global change (Walters and Vayda 2009; Goldman et al. 2011). The understanding of decision-making processes in flooding situations is improving through empirical studies using ad hoc survey methods. Although many efforts lead this way, a holistic comprehension of the main contributing factors is still challenging because of the heterogeneity of the methods used (Parker et al. 2009). This paper contributes to this effort, proposing an "event-based methodology" (Walters 2012) to collect data in the context of postflood investigations.

One of the main goals is to understand why people decide to travel in hazardous weather conditions and how they adapt (or do not adapt) their activities and schedule in response to environmental perturbations. This requires an integrated approach, sensitive to the spatial and temporal dynamics of geophysical hazards and responses to them (Drobot and Parker 2007; Morss et al. 2011). The Coupled Human and Natural Systems (CHANS) approach offers an interesting theoretical background for the analysis of interactions between environment and society (Liu et al. 2007). In particular, the spatiotemporal framework proposed by Holling (2001) constitutes an interesting tool for integrating both physical and social factors involved in the individual response to flash flood. Its multiple scales perspective allows taking into account the variability of these factors depending on both the dynamic of the hydrometeorological event and the dynamic of the social response (Ruin et al. 2008; Creutin et al. 2009, 2013).

In the case of flash floods, the time available to "anticipate" the danger varies dramatically in space and according to the size of the drainage area upstream of the point of interest. In general, as catchment size decreases, the delay between rainfall and flood peak decreases. More importantly, the shorter this delay is the 
faster the water level rises in the river. In addition, the absolute time of danger outburst varies in space according to storm characteristics, and the appropriateness of individual and group response across space scales is hard to assess (Creutin et al. 2009, 2013). For instance, the timeliness of a reaction may be perfect at a point within a large basin, while the same reaction performed at the same time at a neighboring point prone to a small, faster-reacting catchment may be inappropriate and late.

To evaluate the timeliness of the individual's reactions with respect to the surrounding hydrometeorological dynamic, we need to capture both routine and complex rescheduling processes and to understand how much of this is related to the hazardous hydrometeorological conditions. The observation of activity rescheduling decision processes has been developed recently in transportation studies (Doherty and Miller 2000; Roorda et al. 2005; Clark and Doherty 2010). These studies often combine various survey methods as questionnaires, diaries, and in-depth interviews together with GPS tracking in order to "capture both routine and complex scheduling processes as well as observe those scheduling decisions made during the actual execution of the schedule" (Doherty and Miller 2000). The proposed methodology for the postflood investigation is derived from such a method.

\section{b. Postevent field investigations: Method and practice}

The proposed methodology is designed to collect the pieces of evidence needed for both understanding the hydrological context and behavioral responses. The following subsection describes the survey tools and methods that were designed to collect such datasets.

The field campaign distinguishes two phases. In the first phase of the field campaign, termed "REXhydro," the witnesses were asked about the timing and dynamics of the event. The main objective of this team was to determine the peak discharge estimations based on hydraulic considerations (Gaume et al. 2004; Gaume and Borga 2008) and to evaluate the related flood dynamics on a range of spatial scales by questioning witnesses close to the studied river sections. This phase also allows for identifying a first list of persons susceptible to be interviewed (in the second phase of the study) about their behaviors during the flood.

This second phase, going by the name of "REXsocio," aims at collecting individuals' own stories through semistructured interviews. It especially focuses on collecting timing and spatial information related to the evolution of the environmental conditions and the individuals' location and pace of activities. Its objective is to document how individuals switch from routine activities to emergency coping behaviors. Inspired by the activity-based approach, it is structured around a chronological guideline with which we invited interviewees to recall what they perceived from their environment, what actions they took, and who they interacted with at the various places they stayed while moving in between places (Fig. 4). The interviewees were asked to tell their story from 15 June at noon. To help localize and collect more accurate information, we offered them the opportunity to locate the various places and draw their itineraries on street plans and/ or road maps.

During the June 2010 storm event, the flood hit all the downstream part of the Argens watershed $\left(2700 \mathrm{~km}^{2}\right)$. As our objectives were to test the influence of flooding dynamics on human behaviors and also to understand how anticipation time and adaptation strategies would still happen even in fast-reacting catchments, we decided to focus on strongly impacted locations within relatively small catchments where the rivers' responses range from less than a half hour to a few hours. We concentrated our data collection efforts on three close-by municipalities: Figanières (2572 inhabitants), Trans-en-Provence (5513 inhabitants), and Draguignan (37649 inhabitants). Catchments' sizes in the different locations surveyed ranged from 4 to $196 \mathrm{~km}^{2}$ (Fig. 5).

The interviews were conducted using a "snowball" (nonprobability) sampling strategy in order to capture the effect of social networks in triggering emergency reactions. By crossing the individual stories, we were able to confirm the timing and spatial characteristics of both the social and hydrometeorological event. Furthermore, the snowball method enables the reconstruction of the social network and personal interactions emerging during the event.

The survey campaign started with interviewing the contact persons listed by the REXhydro team. While these people were telling us their stories, we asked them to identify any other people with whom they were in contact (directly or indirectly) at various stages of the event. Then, as much as possible, we interviewed all the contacts they mentioned to get a more precise idea of the specific situations in which they were all involved.

The data collected vary in nature. The first information includes narratives related to the type of places, activities, social interactions, and environmental circumstances contextualizing each individual's reaction. The second type of data consists of the location and time data necessary to relate each performed activity within the very specific environmental circumstances in which they took place. A total of 38 interviews were collected. Among them, 29 were complete and reliable enough to be used 


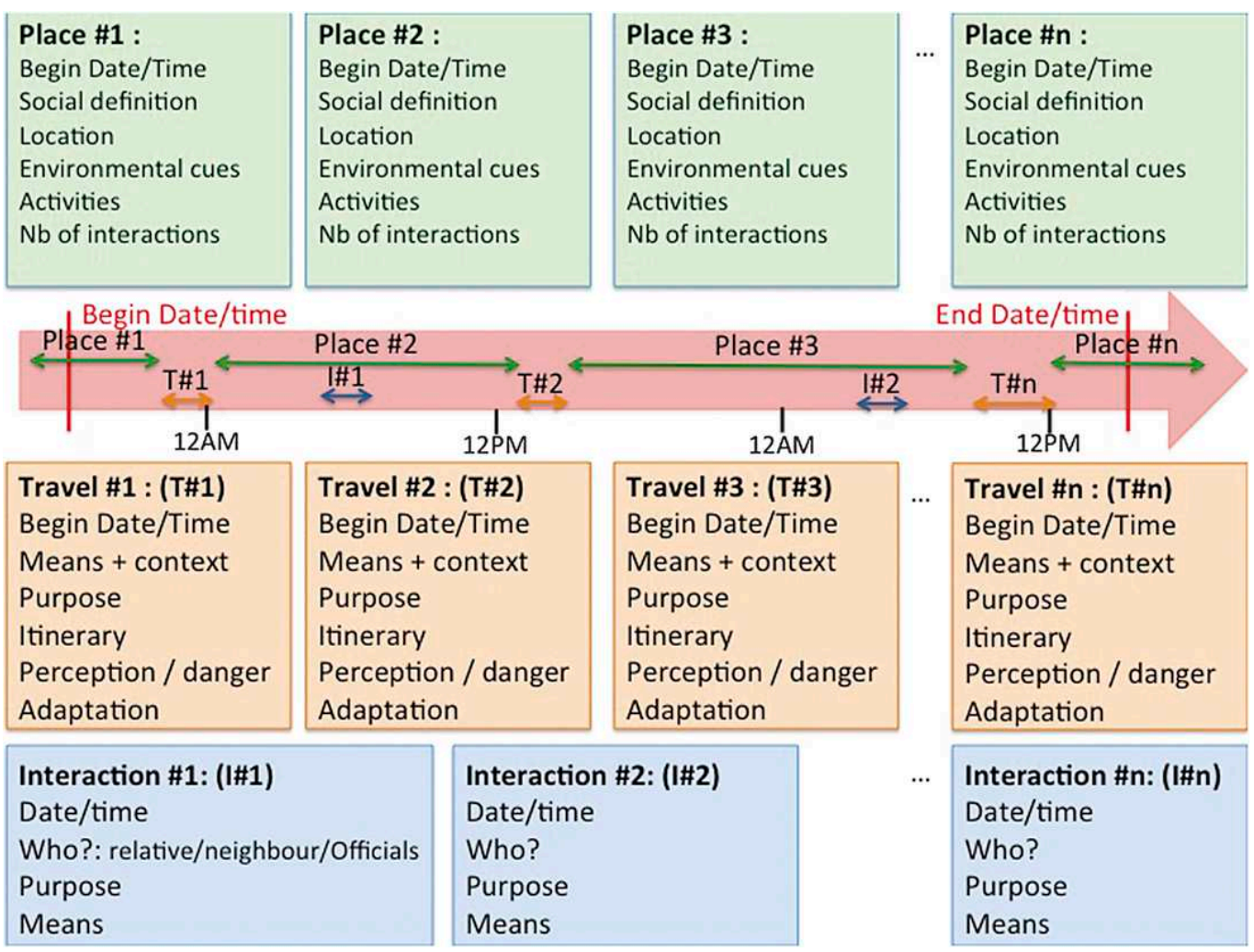

FIG. 4. Semistructured interview framework used for the REXsocio to collect 29 testimonies in three municipalities affected by the June 2010 floods in the Var area.

for the analysis. Based on where respondents were when they took action, 16 interviewees were concerned with the flooding of small catchments (less than $20 \mathrm{~km}^{2}$ ) and 11 persons with larger ones (approximately $200 \mathrm{~km}^{2}$ ) (Fig. 6). Two other respondents interviewed in Trans and Draguignan are part of the analysis but could not be represented in Fig. 6 as their reaction could not be attributed to a specific catchment in the study area.

\section{The possible causes of the individual's response timing}

This section examines a few individual's stories that illustrate key lessons learned from a comparative analysis. The stories reveal some common points concerning the way people coped with the timing of the event. In an abductive process (Walters 2012), our purpose is to define the possible causes of these responses based on the observed actions performed during the event (the effects).

\section{a. A general sense of lack of anticipation}

Comparing the timing and geographic distribution of the protective actions, together with the flood stage's testimonies collected through the REXhydro (as shown by Fig. 7), shows that very few respondents actually anticipated the threat of the flood. As mentioned earlier, even if most of the protective actions started before the estimated time of the peak flows (considered here as the peak of danger), people did not really anticipate the flooding stages that would inundate the buildings.

For exemple, the story of one of our respondents working at the Var region firefighter coordination office (service départemental d'incendie et de secours, SDIS) in the upper catchment of the Riaille in Draguignan is particularly illuminating. Until 1630 (LT), even knowing the orange vigilance level was on, the SDIS was only dealing with communication issues to report the crisis due to the flooding of the prison in a neighboring area of the city. The potential flooding of the SDIS building was not foreseen and therefore firefighters were not prepared to secure their rescue teams and equipment. At 1630 the water was entering the street and then the courtyard of the SDIS $5 \mathrm{~min}$ later. The level of the water was up to the tires at 1730 and was still rising. Around that time, people started to move the cars to the SDIS courtyard for protection and then to climb upstairs as they were trapped in the SDIS building. At 1830 telephone service was disrupted and no more 


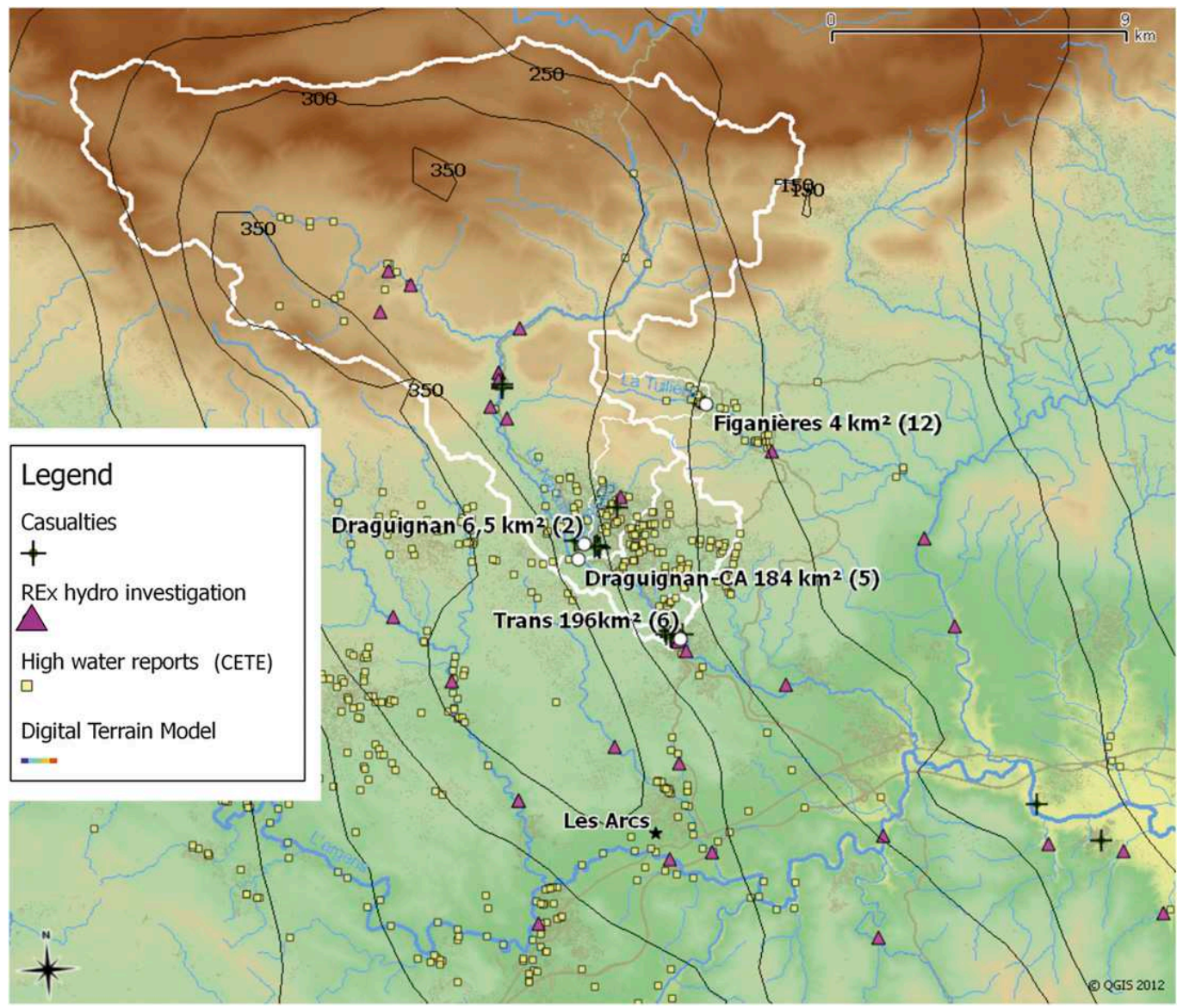

FIG. 5. Distribution of the number of interviews collected (in parenthesis) in each catchment (white lines) and outlets (white dots). The black isolines display the total rainfall accumulation over the event. The small yellow squares show the location of flood stage timings collected through the first round of the postevent investigations. The location of the fatal accidents during the event is also displayed with black crosses.

communication was possible with the outside. The water reached the windows of the cars at 1840 , then the cars' roofs at 1950. At that time, our respondent escaped the building swimming with the purpose of helping the imperiled people in the neighborhood. His dangerous rescue tasks lasted until 2200 after he failed collecting his wife (case 13) who was waiting in an improvised shelter in a close-by neighborhood. Eventually, he managed to get back to his home that was out of the flooded area to recover.

Several other examples show, like this one, the difficulty for people to take timely protective actions. Even if some of them did receive official warnings (the orange vigilance in this case) relatively early, it did not trigger immediate reactions; many looked for confirmation of the information through other sources and oftentimes by looking or waiting for environmental cues to become obvious. Similarly, if some people started to organize themselves or protect their goods quite early compared to the local flooding dynamic, they somehow hardly managed to adapt the pace of their protective reaction to the pace of the river response and ended up protecting their own life at the last minute. As was already shown in previous works (Parker et al. 2009), the official warning is not sufficient information for acting properly, even in the emergency services. The ability to anticipate the possible event is crucial but dramatically reduced in flash flood cases, and the timing of the event appears as a key factor.

\section{$b$. The difficulty of making sense of the situation}

Because flash flooding environmental conditions vary tremendously across space in very short amounts of time, it is often difficult for victims to comprehend the situation in which they are embedded or to imagine the variability of the threat when moving across space. Several stories collected during the interviews emphasize this issue. 


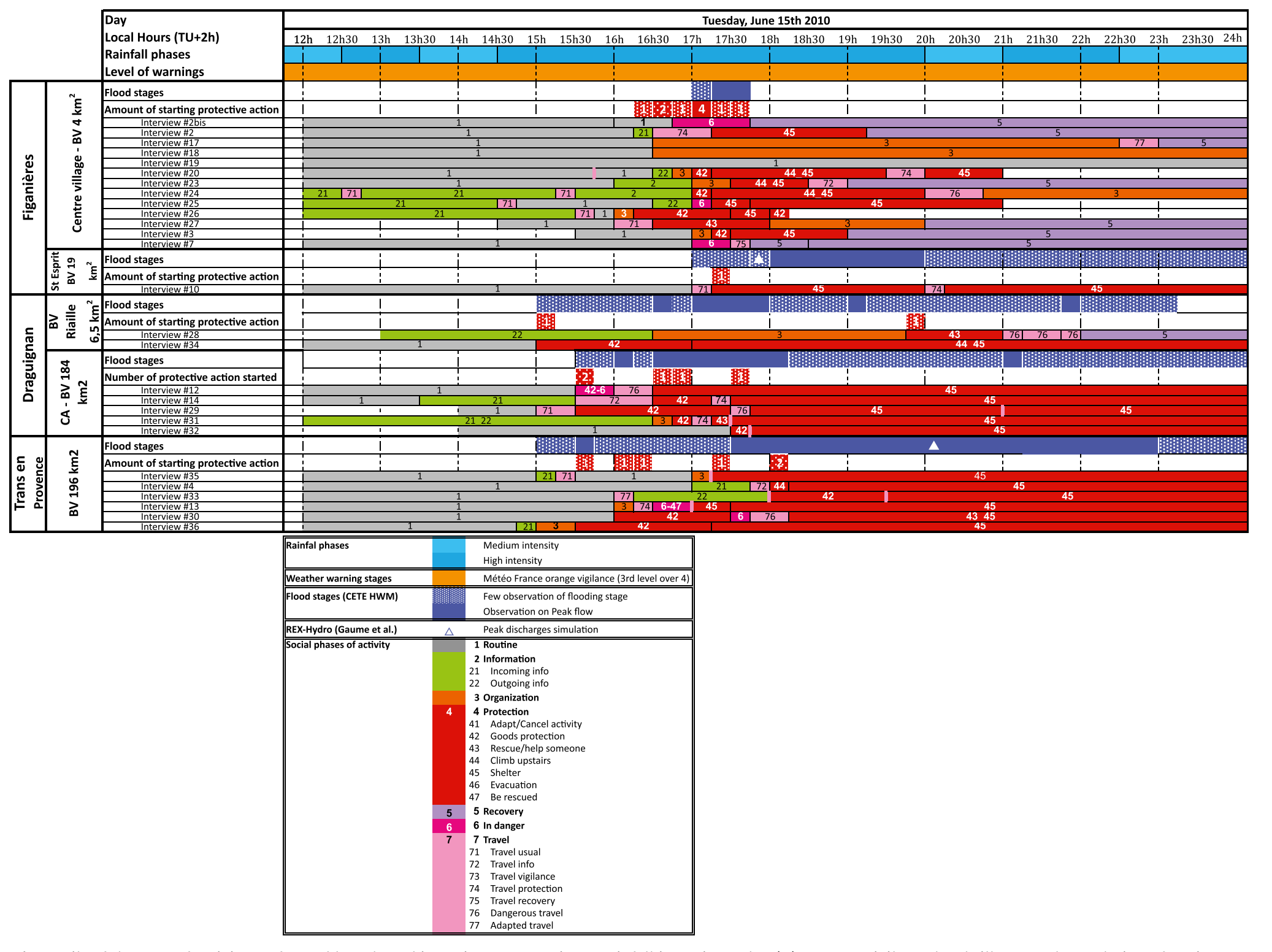

FIG. 6. Details of the type of activity performed by selected interviewees over time. Rainfall intensity and Météo-France vigilance levels illustrate the evolution of environmental circumstances over the study area. In addition, flood stages observations issued from the REXhydro investigations are displayed for each catchment. 


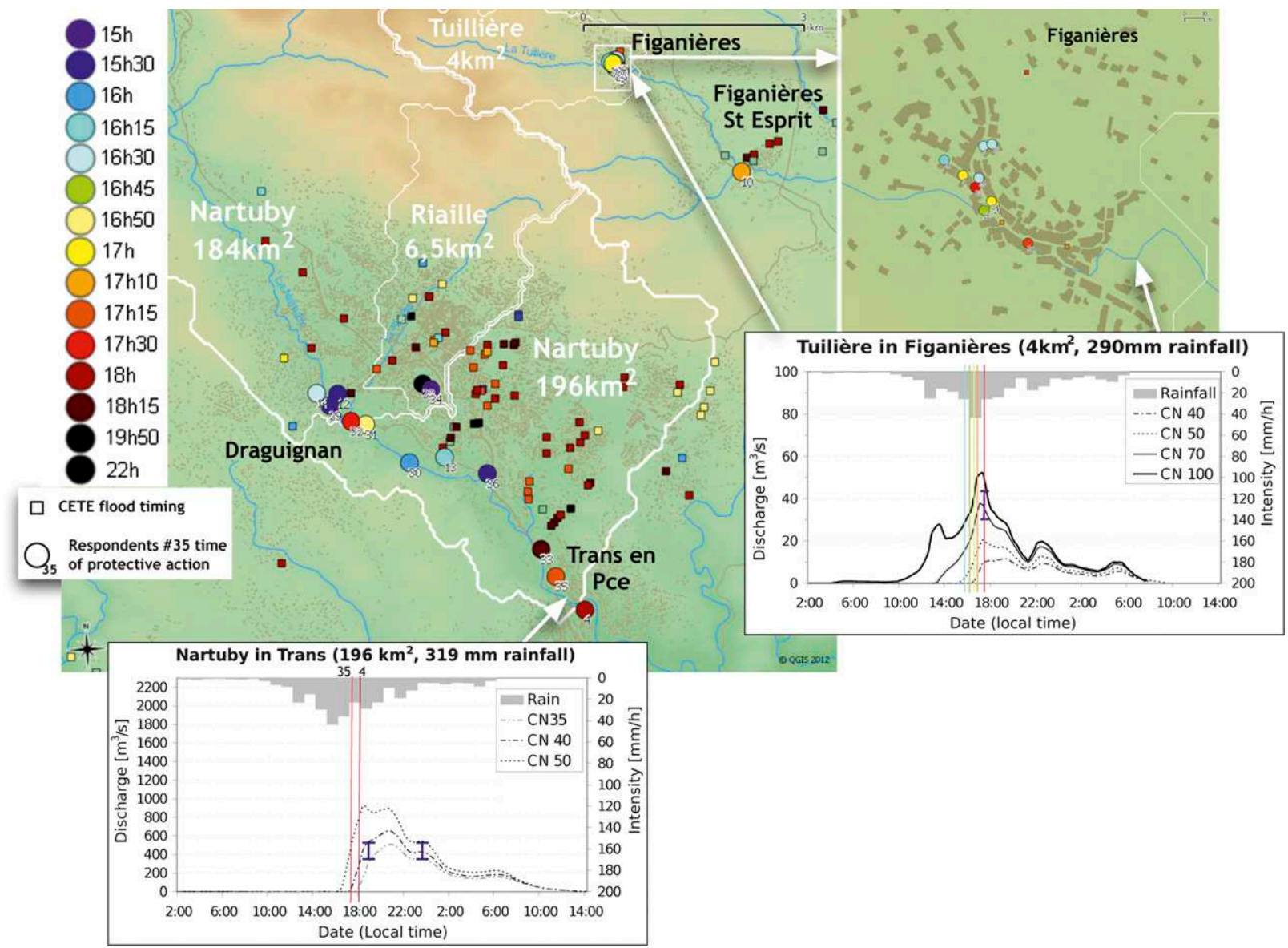

FIG. 7. Space-time distribution of the hydrological and behavioral data for 15 Jun 2010. Dots show where protective actions took place, and the color code displays the starting time of each individual's action. Colored squares show the time of the runoff peak flow estimated from hydrological postevent investigations. Related peak flow simulations from Payrastre et al. (2012) for the Nartuby and Tuilière Rivers are displayed, and the timing of protective actions in those catchments are reported on the hydrograms with colored lines.

The story of respondent 19 is a good example of people who learned about the catastrophic flash flooding affecting their neighbors or relatives through TV news the next day. As an 86-yr-old man living alone in his house, he did not learn about the flood before the next morning when he went to buy his bread in downtown Figanières and discovered the damage in the main street. Fortunately, his house, located on the hill, did not get threatened. As already shown in a previous study, this kind of reaction seems to mostly concern the elderly who are often more socially isolated or marginalized (Ruin and Lutoff 2004).

Cases 13 and 36, related to each other, highlight other kinds of difficulties related to making sense of the situation. On the one hand, they tell us the story of a woman (case 13) who by attempting to help her mother flooded at home got caught on the road in a very dangerous situation. Knowing her parents' home location is prone to flooding, she called her mother around 1600 and learned there was already $2 \mathrm{~cm}$ of water inside the house. Then she called her father, who was involved as a firefighter in the flood rescue. He advised her to go and help her mother if it was still possible to access the residence. Then she left her work place in downtown Draguignan at 1620 and drove toward her parents' home located $2 \mathrm{~km}$ away. Encountering water on the way, her car stalled about $500 \mathrm{~m}$ before her parents' house. At first she felt safer in her stranded car until the vehicle started to float. Unfortunately, she was stuck inside with too much pressure on the doors to open them and no power to open the electric windows. After being trapped in the car for $25 \mathrm{~min}$, she finally managed to restart the engine, open the electric windows and escape, fighting against the current, with the help of a man who happened to be around. On the other hand, her mother (case 36) was accustomed to having her house flooded. She anticipated and reacted appropriately to the event by following her own safety procedure (we will come back on this later), 
starting as soon as 1500 (which is very early). Nevertheless, she was thinking that only her house got flooded (as usual) and therefore she did not understand why her daughter, on the way to help her, would not arrive. She only learned about her daughter's situation at 0300 when her brother living in Marseille called her to give her the news that her daughter was safe.

These latter examples show the strong but equivocal influence of experience on preparedness and the individual's ability to make sense of the situation and for "self-warning" (Parker et al. 2009).

Several cases demonstrate the importance of being able to capture environmental cues in this self-warning process. For instance, reacting to the Nartuby River flood in Trans-en-Provence, respondent 4 started to actively protect her goods and the merchandise from her shop together with her husband around 1800 . Her reaction was triggered by the accumulation of cues within the preceding hour. First, she was alerted by shoppers who reported road flooding and $1 \mathrm{~m}$ of water near Trans town hall. Then the power went off. Finally alerted, she walked toward the river to see for herself what was going on. Flooding was ongoing and as she said, "The old bridge over the river was trembling with people standing on it." Back in her shop, she found the water was starting to enter. Then, together with her husband, she saved important documents and climbed upstairs to their flat (located above the store).

The environmental cues may become decisive because they have significance through the specific history or experience of the witness. Here again, the experience of analog situations appears as a key factor. The story of respondent 20 gives us a better insight about that process. In the case of this shopkeeper of the main street of Figanières, her decision to evacuate upstairs was prompted by hearing the creak of her entrance door that was being pressured by the flooding water. When she heard the noise, it reminded her of the sound of a wildfire that she experienced before. So she got frightened about her own situation and of the ones of her employee and the shopkeeper next door and hurried everyone to go to safety together.

However, sometimes the experience may play an equivocal role in the sense-making process. Respondent 14, a shopkeeper of the Draguignan-Commercial Area (CA), was informed of the first runoff problems in her shop by a phone call from her employee as early as 1330 . At that time, she did not quit her routine and finished attending her meeting. At 1530, because of traffic, it took her an hour to drive back to her shop to see by herself what was happening. When entering the store, as she was used to having her shop invaded by rainwater coming from the surrounding parking lots and poor drainage, she first started to deal with the supposed obstruction of the sewer system. She finally decided to move her car to higher ground. When she went out by the riverside she realized the danger was coming from the river and not from the parking lot. She managed to park her car on high ground and called her employees who had stayed in the store and told them to evacuate immediately.

Making sense of the situation appears to be a key element of the decision-making process in flash flood situations. The testimonies collected during the 2010 flash flood in the Var emphasize the essential but equivocal role of previous experiences in this process.

\section{c. Emerging self-organization and the emergence of a collective response}

Fortunately, the general lack of anticipation or the difficulty of making sense of the situation is often compensated by self-organization and the emergence of helpful social interactions.

A first example of self-organization comes with the story of respondent 36 (already evoked). Because her home had already been frequently flooded (and maybe because she is married to a firefighter), she was well prepared for flooding and had made her own "flooding checklist." She started, as early as 15:00, to follow the various steps by (i) checking the level of the water that was still $40 \mathrm{~cm}$ below the level of the house, (ii) requesting that the parents of the three children she takes care of come to pick them up, (iii) driving the three cars to higher ground, and (iv) securing her important papers and eventually calling her husband to ask him what to do when the water entered the house at 1715 . On his advice, she evacuated her single-story house together with the last 2-yr-old child whose mother was not able to pick up the child fast enough. They went to the first floor of her mother's house next door.

As for the emergence of a collective response, it is interesting to look at three testimonies (cases 30, 31, and 32) recollecting a story that happened in Draguignan-CA. It shows how much "unofficial" warnings or improvised emergency action may be influential in lessening the impact of flash flood events. The action started with respondent 31 who interpreted the environmental cues of refrigerators floating in the river as a serious indicator of danger and initiated the process of protecting himself at 1650 . On his way to evacuating he went to the shop nearby (respondent 32) as he knew one of the employees working there. When he saw the people trying to keep the water (which was already about $30 \mathrm{~cm}$ deep) from entering the store, he realized they were not understanding the situation correctly and argued for them to evacuate with him. Nearly simultaneously, respondent 
30 , passing by on his way to evacuate warned them too, saying "if you don't leave you will die." Finally around 1745 , respondent 32 and the other employees agreed to take protection following respondent 31 to the upstairs of a neighbor's warehouse.

Beyond the simple interactions between people, this story illustrates the emergence of collective response that takes place when individuals need to improvise a reaction to face unexpected circumstances together with people who are in the same location at that time. Emergent groups may be composed of people who already knew each other before the flood, as it was partly the case in the previous story. This is more likely to happen in places where people have their habits like home or work places. But collective response also happens among people who have never interacted before (see case 13 described in section $3 b$ ) and may never interact again after. As seen in case 13, this might happen when people are traveling, especially when moving outside of their usual area of practice.

\section{d. Conflicting priorities and the beneficial influence of a third party}

Sometimes, even when the threat becomes obvious, environmental cues are not even acknowledged nor considered sufficient by those at risk to overcome their daily life's priorities. This was the case for many of our respondents.

The story of respondent 32 in Draguignan-CA also shows that the man was still in a "routine" mode, while other respondents around had already started to take protective measures (Fig. 6). At that time, this business owner and director was in his store busy dealing with the installation of newly arrived merchandise. He only agreed to evacuate $30 \mathrm{~min}$ later after being warned by several people and after the water had largely inundated the shop.

Another example demonstrating both the difficulty of making sense of the situation and prioritizing work's responsibility, two employees (only one was interviewed) of a store ended up being in a dangerous situation by spending too much time trying to save merchandise. Both women were working when the water started flooding the shop. At first they thought it was only runoff because of the slope of the parking lot. Their reaction was to protect the merchandise by raising it up out of the flood water's reach. They only felt the need to run away when the water reached their hips about an hour later and after their employer, who they talked with on the phone, advised them to leave. By the time they escaped on foot, cars were already floating around. Luckily, they finally managed to reach a hotel uphill that ended up serving as an improvised shelter for the area.

A similar and even more striking case happened in Figanières and shows how much the presence of a detached party can fortunately influence the decisionmaking process. The story involved a young pregnant business owner (respondent 25) accompanied by a friend (and client whom we did not get to interview) and a municipal employee who came to help (respondent 27). The two women were trapped in the respondent's shop located downstairs from the main street. The flood water running along the street was about $0.5 \mathrm{~m}$ deep (above the street level), which meant nearly $1.5 \mathrm{~m}$ above the floor of the shop. ${ }^{3}$ The only way to escape the shop was to open the window where the municipal employee was standing and try to convince the women to leave. From the interview, we understood that the business owner did not want to open the window because she was not thinking of her own security but, rather, she was afraid that her newly started business would be damaged. It was thanks to her friend who had no emotional nor financial involvement with the business that they finally opened the window, broke through the wall of water (thanks to the help of the man outside), and were able to survive unharmed.

\section{The pace of individual responses}

\section{a. The individual responses dataset}

Based on this first analysis and inspired by activitybased analyses in mobility and transportation studies, the narratives were coded to reflect the various types of situations reported. The variable called "place" was coded to show the type of social places where people were located such as the workplace, a dwelling, or a public building. From all the answers received we distinguished eight categories (Fig. 8). We hypothesized that the type of place where people are situated might influence individual responses to warnings, as it has been argued in previous research that coming back home and gathering the family there is one of the first drivers of behaviors during a crisis (Drabek 1986; Mileti 1995). The variable called "activity" codes the type of behaviors. Four main categories were selected with the objective of capturing the transition from routine activities that are qualified as "usual" and crisis activities including three gradual states that qualified in previous work as "information", "organization," and "protection" (Creutin et al. 2009). Three more categories were added: 1 ) "recovery" was attributed to postemergency action, 2) "in danger" was used to indicate that the individual's situation was life threatening, ${ }^{4}$ and 3) "travel" was used to

\footnotetext{
${ }^{3}$ The shop is located in the basement of the building.

${ }^{4}$ According to the interpretation of the researcher based on the description the victim made of the situation.
} 


\begin{tabular}{|l|c|}
\hline Places & $\begin{array}{c}\text { colors/ } \\
\text { codes }\end{array}$ \\
\hline Work or school & 1 \\
\hline Home & 2 \\
\hline On the road & 3 \\
Driving & 31 \\
Walking & 32 \\
Zodiac & 33 \\
Bus & 34 \\
\hline Relatives or neighbours & 4 \\
\hline Emergency management center & 5 \\
\hline Public building & 6 \\
\hline Improvised Shelter & 7 \\
\hline Outdoor & 8 \\
\hline
\end{tabular}

\begin{tabular}{|l|c|}
\hline Activities & $\begin{array}{c}\text { Colors/ } \\
\text { codes }\end{array}$ \\
\hline Usual & $\mathbf{1}$ \\
\hline Information & $\mathbf{2}$ \\
I. incoming & 21 \\
I. outgoing & 22 \\
\hline Organization/vigilance & 3 \\
\hline Protection & 4 \\
Adapt/Cancel activity & 41 \\
Goods protection & 42 \\
Rescue/help someone & 43 \\
Climb upstairs & 44 \\
Shelter & 45 \\
Evacuation & 46 \\
Be rescued & 47 \\
\hline Recovery & $\mathbf{5}$ \\
\hline In danger & $\mathbf{6}$ \\
\hline Travel & 7 \\
As usual & 71 \\
For information purposes & 72 \\
For Vigilance purposes & 73 \\
For protection & 74 \\
For recovery & 75 \\
Dangerous travel & 76 \\
Adapted travel & 77 \\
\hline
\end{tabular}

FIG. 8. List of the color and numeric codes used to process the qualitative data collected through 29 semistructured interviews conducted in the Var area on November 2010.

emphasize periods when respondents were moving between stations or were in transit, as those might be factors of enhanced exposition to flash flooding and a lesser perception of danger (Ruin et al. 2007, 2008). Under the categories of information, protection, and travel, subcategories were created to precisely identify the various goals of such activities. The list of the categories and subcategories employed for the coding are listed in Fig. 8.

The data file issued from the coding of the interviews is structured around three distinct sets of variables. The first one gathers sociodemographic data about the respondent: gender, age, and profession. The second one gathers six variables describing the stations or fixed locations where the respondent spent time and the related action(s). These variables include latitude and longitude, starting time and ending time, and place code and activity code. A block of station data is entered each time a new location, place, or activity has been reported and can be easily delimited in time. This means that if the person stayed at home the entire time but declared, for instance, that he or she switched his/her activity from daily routine to an organizational stage at a certain time, a new block of data is entered with the same geolocation and place code but with a different activity code reflecting its switch to an organizational activity during this specific period. The third set of two variables codes is for the travel modes (four modalities) and purposes (seven modalities) (Fig. 8) occurring in between the stations or locations. Therefore, one person might have a pattern of a data block describing a series of stations and travels.

\section{b. Dynamics of the hydrometeorological event as a reference}

To compare the type and pace of individual responses, we used the reference of the flood timing, common for a specific location. The flood phases have been identified thanks to the data collected through the REXhydro (Payrastre et al. 2012). A comprehensive review of meteorological and hydrological datasets was conducted before proceeding to field measurements. Information about high water marks and the floods' timing were collected in the field a few days after the event by the Centre d'Études Techniques de l'Équipement (CETE) Méditerranée (CETE 2011).

The estimation of maximum peak discharges based on measurements of river sections, high water marks, and estimation of flow velocity reported by witnesses are the result of the REXhydro field investigations (Payrastre et al. 2012) according to the method developed by Gaume and Borga (2008) and Borga et al. (2008). The hydrograms in Fig. 7 are issued from distributed rainfallrunoff simulations (Cinecar model) using different curve numbers $(\mathrm{CN})$ of the Soil Conservation Service (SCS) model with the value in the range of 35 (retention capacity of the soils up to $472 \mathrm{~mm}$ ) to 100 (constant runoff 
coefficient equal to $100 \%$ ) (Gaume and Bouvier 2004; Gaume et al. 2004).

According to radar data on 15 June 2010 rainfall was light over the areas of interest from the end of the night until 1030 in the morning, causing a rain amount of $5 \mathrm{~mm}$. Then the intensity increased significantly between 1030 and 1230 , causing an additional amount of $15 \mathrm{~mm}$. Starting from 1230 on 15 June 2010 and up to 2000, steady rainfall intensities around $30 \mathrm{~mm} \mathrm{~h}^{-1}$ were observed with several peaks of more than $50 \mathrm{~mm} \mathrm{~h}^{-1}$. The total precipitation at 2000 was respectively 175,220 , and $205 \mathrm{~mm}$ over the Figanières, Draguignan, and Trans watersheds. The rainfall intensities remained around $8 \mathrm{~mm} \mathrm{~h}^{-1}$ a few hours after 2000 and weakened during the night. The rain finally stopped at 0600 on 16 June. Ultimately, 258, 306 , and $311 \mathrm{~mm}$ were respectively estimated in Figanières, Draguignan, and Trans.

According to the hydrological postevent investigations, the dynamics of the floods in each location were quite different. The flooding of the small catchment of the Tuilière River at the outlet of Figanières village $\left(4 \mathrm{~km}^{2}\right)$ started around 1700 and lasted about $30 \mathrm{~min}$ (Fig. 7), with fast moving water overtopping the main street of the village by $1.60 \mathrm{~m}$. A few kilometers farther down the village, at the outlet of Figanières-Saint Esprit $\left(19 \mathrm{~km}^{2}\right)$, the flood seemed to have started slightly later and the inundation was reported to have lasted until 0700 the next morning. The flooding of the Riaille seemed to have started a little later ( $30 \mathrm{~min}$ to $1 \mathrm{~h}$ ) than the flooding of the main river, which began at 1530 on 15 June. The Riaille peak flow happened around 1700 and 1800 , while the Nartuby was at its maximum between 1630 and 1815. In Draguignan, 10 people died from the flood, and at least one casualty was clearly attributed to the Riaille. Most testimonies about the flood stage indicate the flooding began Tuesday 15 June after 1500 and finished on Wednesday morning 16 June. In this village, the Nartuby River rose to its maximum around 1800 and stayed at its peak (or had a second peak) until 2300 (Fig. 7). The speed of the flow of the Nartuby entering a gorge in Trans-en-Provence killed five people, destroyed a few buildings close to the river, and triggered a landfall affecting the cemetery.

\section{c. Coping response versus hydrometeorology}

To allow a comparison of the coping response and the flooding dynamics in each catchment, Fig. 7 displays the chronology of each respondent's activity according to the location where they started to take protective actions.

At the time protective activities started 16 respondents had to cope with fast-reacting catchments: 14 in Figanières related to the flooding of the Tuilière River basin and 2 in downtown Draguignan because of the
Riaille River. In Figanières, 10 respondents started to react within the same timeframe of about $1 \mathrm{~h}$ (1615-1730) (Fig. 7). Compared to the flood stages reports from the CETE, most of the protective actions started after 1630, anticipating the time of the peak flow by at least $15 \mathrm{~min}$. Two respondents reacted either simultaneously or late and three respondents $(17,18$, and 19$)$ did not need to take protection measures because they were out of the flooded area. The only two testimonies we have in downtown Draguignan show a very different timing with a first, early reaction at 1500 and a second $5 \mathrm{~h}$ later.

The 11 respondents located near the Nartuby River were concerned by the flooding of larger catchments. In the larger catchment of Trans-en-Provence $\left(196 \mathrm{~km}^{2}\right)$, the six behavioral responses are spread over $2.5 \mathrm{~h}$ with most people responding before 1630. In DraguignanCA, drained by the Nartuby $184 \mathrm{~km}^{2}$ basin, the five protective actions happened in a time window of $2 \mathrm{~h}$ but most of them started after 1630. According to the flood stage reports and peak flow simulation, flood responses seemed to have been a little more anticipated in Trans than in Draguignan-CA. When the interviewees initiated coping responses, 16 of the respondents were at work, 9 were outside buildings (including 5 traveling either by car, by bus, or walking), and 2 were at home.

To give an overview of the coping response and its environmental circumstances, Fig. 9 displays the proportion of interviewees by type of activity over time together with the rainfall intensity over the Trans watershed. According to the figure, the event is divided into four periods that correspond to the evolution of the hydrometeorological context.

The first phase is before 1400 with a first important precipitation sequence cumulating about $60 \mathrm{~mm}$ but without any serious runoff or river reaction. The orange vigilance level launched by Météo France the day before seems to have slightly increased awareness but it had negligible effects on people's preparation. In fact on 15 June at noon nearly all the respondents (91\%) were immersed in routine activities. From 1215 to 1345 , the number of people in routine mode decreased to the profit of the information mode peaking between 1330 and 1345 , with $24 \%$ of the respondents. The information activity increased until 1335 and matches the first peak in rainfall intensities (which occurred around 1245). During that period, only six people expressed some kind of awareness related to the hydrometeorological event. Four of them explicitly said they became aware of the Météo France storm watch (orange vigilance level) for the Var area when they were watching the midday news on TV at home during their lunch break. According to what they said, this information did not affect their plans for the day or their level of 


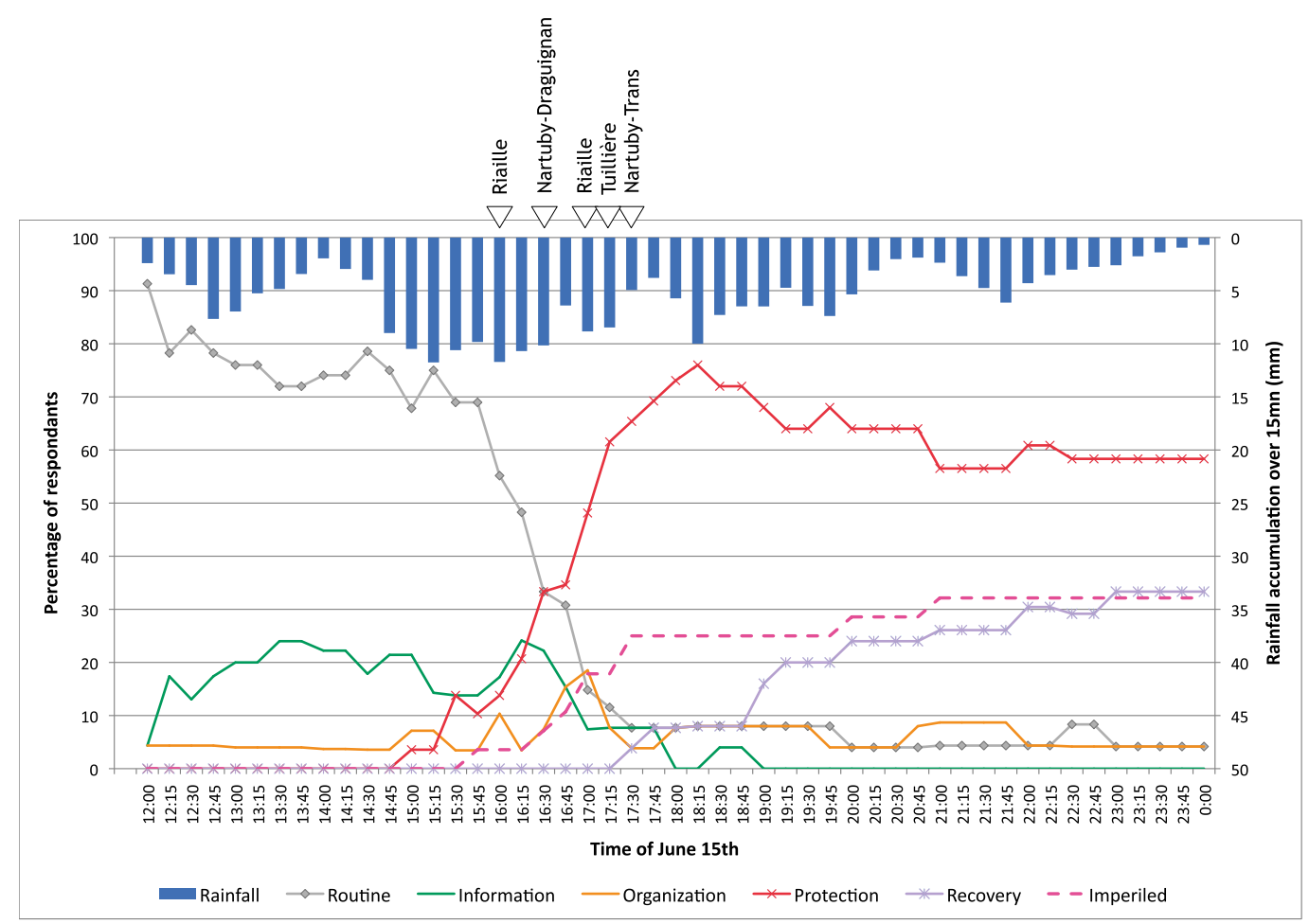

FIG. 9. Time evolution of the percentage of respondents by type of activity and corresponding areal rainfall intensity and time of peak flows over the study area $\left(196 \mathrm{~km}^{2}\right)$. Time step is $15 \mathrm{~min}$.

concern. One of them did recommend that visiting relatives should bring boots and raincoats. One person (31), who had a direct upper view on the Nartuby River from his working place, felt concerned by the environmental cues. Respondent 14 was warned by a phone call from one of her employees reporting the first runoff problems in her shop that was situated a few meters from the Nartuby River in Draguignan-CA.

Phase two, between 1400 and 1630, corresponds to the flood precipitation-generating sequence that added $90 \mathrm{~mm}$ to the first phase. During that period, intense surface runoffs were already taking place in some areas. The number of people switching to protective action only starts to increase at 1500 , shortly following a second and major rise in rainfall intensities and just before the occurrence of the first peak flow at 1530 in the lower part of the Nartuby catchment. In total, only three people reported that they switched to an organization mode and seven others to a protection mode. As shown by the pink dashed curve representing the cumulated percentage, the number of imperiled respondents starts to rise slowly at 1545 as one person (12) found herself in a dangerous situation in the commercial area of Draguignan, not far from the confluence of the Riaille and the Nartuby Rivers.
Comparing the timing and geographic distribution of the protective actions together with the flood stage's testimonies collected through the REXhydro, Fig. 7 shows that for some respondents protective actions were mostly synchronized with the beginning of the water rise. This was the case for respondents $12,13,29,30,34$, and 36 in the Draguignan area and 26 in Figanières. Based on those testimonies, most protective actions only started when some water entered the work place or dwelling where people were located. One exception was 13 whose first protective action was to drive to her mother's place to help her dealing with the flooding. All the other respondents' reactions were to elevate merchandise above the flood level and/or to move their car to higher ground. This is the only type (code 42 on Fig. 6) of protective actions that took place during that phase. Our respondents dedicated quite some time (from $30 \mathrm{~min}$ to $2 \mathrm{~h}$ ) to this activity that often ended up with them being in dangerous situations, either during this same phase (12) or during phase three (29 and 30). In Figanières, even if a few people started to feel concern about the environmental cues, only one person (26) reached an organization stage during this period by first trying to figure out the first runoff problems in front of her shop and then raising the goods in her shop as the water entered. 
Phase three, from 1630 to 1815 , corresponds to the flood danger outburst constituting a powerful "pace maker." This phase cumulated $40 \mathrm{~mm}$ more rainfall to the previous rainfall for a total amount of 70 to $200 \mathrm{~mm}$ from the east to the western part of the area. It triggered major peak flows in all of the studied rivers. This period follows a drop of the routine, information, and organization curves to the profit of the protection curves that reaches an inflection point around 1645, when the switching rate is at its highest. In total, during that period 18 respondents were forced to take protective actions against the inundation, including 3 only switching to an organizational stage. Most of them were either in Figanières (12) or in Draguignan (4). Because of the time of the day most people were at work when they had to take protection and most of the dangerous travels during that phase were related to the purpose of protecting oneself or rescuing someone. In Figanières, officials started to become aware of the abnormality of the situation around 1630 when they started to get several phone calls from inhabitants reporting runoff problems in the main street of the village. The first rescue operations (using municipality resources only) started shortly after. It involved few local officials and employees walking toward the locations of the reported problems to figure out what to do. They ended up rescuing people out of dangerous situations as the example of respondent 27 helping 25 to escape the flooding of her shop (as described in the previous section). In Figanières village, the flood was extremely localized, mainly affecting the main street. The flooding was so fast ${ }^{5}$ that even if some people tried to secure their goods at first they rapidly realized that they had to take shelter by going upstairs when that was possible. In the commercial area of Draguignan, the level of the water started to be critical before 1700. Testimonies show that employees and shopkeepers somehow had to make sense and manage the dangerous situations by themselves $(14,30,31$, and 32). Two respondents located in Trans-en-Provence started to take protective action soon after 1800 , as the water started to enter their shops. Both tried to protect some of their merchandise. Interviewee 33 was with his parents who were the owners of the shop. They carried on this task until the water was as high as $60 \mathrm{~cm}$. They eventually escaped by driving back to their home that was close by on a hill and luckily followed a route that was free of flooding.

The number of imperiled people increased steadily between 1630 and 1730 . At that time $25 \%$ ( 7 persons)

\footnotetext{
${ }^{5}$ Testimonies indicate that the level of water in the main street rose $1.10 \mathrm{~m}$ in $15 \mathrm{~min}$.
}

of our sample can be counted as "imperiled." Two of them, immersed in their jobs ( $2 b$ and 7 ) were literally surprised and forced to escape as a survival reflex. Four others $(25,29,30$, and 31) evacuated quite late because of trying to secure goods or worrying less about their own safety than material losses. Another did not feel the danger coming (34) as she felt protected in her car. During that period, as illustrated by the stories described before, self-organization and emerging interpersonal interactions were quite common. Most of our respondents managed to get out of trouble by interacting with other people, some of whom were strangers but who happened to be at the right place and time to help out. Sometimes interpersonal interactions only helped the realization of the danger and emergency of the situation; sometimes physical help was needed.

Finally phase four, starting at 1815 , is characterized by the slow rising pace of recovery progressively replacing protective actions. It also includes the last two precipitation sequences maintaining the peak flow of the Nartuby in Trans-en-Provence until 2300. During this phase, the water level was still rising in some areas, while the Tuilière was going back to its riverbed in Figanières. The ratio of people in protection peaks at 1815 at the same time as the third rainfall peak, when the number of interviewed people performing usual activities is under $10 \%$. Later the protection curve displays smaller peaks that also correspond very well with peaks in rainfall intensities, possibly illustrating enhanced awareness. Then, when the protection rate decreases, the recovery curve starts to rise quite steadily around 1845 to finally stabilize at 2300. The recovery process mainly happens in Figanières, which is coherent with the REXhydro data, relating the fast onset and drop in of the Tuilière River. During that phase, at 2000 and 2100, two more people became endangered while traveling.

\section{Conclusions}

This paper proposes a methodology of postflood field investigation exploring the link between crisis behavioral response and hydrometeorological dynamics in space and time. It aims at contextualizing a limited set of coping responses observed with respect to local hydrometeorological conditions. The analysis of the collected data associates abductive and activity-based approaches. The first one allows the identification of the possible contextual factors influencing individual responses to flash flood. The second one offers a framework for a comparative analysis of the pace of the sequence and type of actions using the flood dynamic as a common reference.

The proposed methodology is useful to compare the pace and timeliness of the social responses across several 
flood events' dynamics and social contexts. Some first attempts of such comparisons were already made across European countries (Creutin et al. 2009; Parker et al. 2009). However, they highlighted the problem of the heterogeneity of the methods used for collecting data. The proposed methodology contributes to addressing this need of standardized and adequate social and physical data collection, not available in existing disaster databases. The use of a chronological guideline for the interviews may appear as a constraint, inducing a loss of richness in the narratives. However, it offers the opportunity to handle these narratives with the activitybased approach and to initiate a quantitative analysis of the timeliness and pace of the sequence of activities with respect to local flood dynamics.

Nevertheless, such methodology still faces some challenges. One of them is related to the timing of the field campaign and survey data collection in order to limit the bias associated with the recollection process. In fact, it is well known that human perception and memory vary across individuals and with the length of time between the perceptual experience and the moment when the survey takes place. Therefore, the most appropriate moment for collecting the data still remains to be defined based on psycho-cognitive considerations. Another challenge that still needs further considerations is related to the proposed categorization of activities. The definition of the categories is inspired by the literature (Drabek 1986; Lindell and Perry 1992, 2004; Mileti 1995; Creutin et al. 2009; Parker et al. 2009). But the process of categorization is based on the researcher's interpretation of the narratives and has to be improved with a more detailed characterization of the criteria used to associate the fragments of the narrative to one specific activity. This work is currently under progress.

Eventually, the application of the proposed methodology on the Var event (15 June 2010) allowed us to identify some possible causes of the individual responses. The difficulty in switching from daily activities to warning responses is one of the reasons and can be explained by the possible conflicts of priorities between routine and exceptional circumstances. The difficulty in making sense of environmental cues in the case of insufficient official warning also appears as a possible cause of delay in the individual response to flash flooding. The study also reveals a form of the individual's self-organization and the emergence of small group responses that may involve different types of social ties depending on the type of area they take place. Finally, the Var data confirms the role of contextual factors, as defined by Parker et al. (2009): the timing of the hydrometeorological event, its severity, and the experience of the flood seem to be essential in the ability of individuals to make sense of the situation and to adapt their activities.
The activity-based approach enables us to divide the sociohydrometeorological event into four phases. The first phase starts with intense rain and mixes routine activities and the search for information. The second phase comes with intense surface runoffs, encouraging individuals to organize themselves and sometimes to engage in protective actions. The first imperiled people appear also during this phase. The third phase comes with the flood danger outburst and is accompanied with the drop of routine or even information or organization activities to the profit of protective actions. The first rescues occur in this phase. Finally, the fourth phase is characterized by a maintained peak flow and a still high level of protective action, with sometimes recovery activities, depending of the flood dynamics. Even though flooding dynamics were quite different according to the catchment size, dangerous situations and lack of anticipation happened both in Figanières' very small catchment, leaving only minutes for reaction, and in the larger catchments of the Nartuby River that reacted relatively slower but still rapidly enough to qualify as a flash flood.

The use of the methodology in other case studies will help in complementing the categorization of the individual pace of reaction. Based on this categorization, it is possible to consider the integration of the individual's coping pace and hydrological responses into a model of flood event dynamics that helps to understand the role played by the social and hydrological parameters and, eventually, to forecast the possible human impacts of flash floods.

Acknowledgments. This work was supported by the French National Research Agency (ANR) through the project ADAPTflood funded by the programme "Retour Post-Doctorant" and the INSU through MISTRALS funding. It is part of the Hydrometeorological Experiment in the Mediterranean (HyMeX) initiative. The authors also wish to thank the CETE Méditerranée (public road administrator), Météo-France, the Cévennes-Vivarais Hydro-Meteorological Observatory (OHM-CV), and Claude Martin for sharing their data. We are also grateful to the Grenoble University (UJF) students and the Greek-French HydroHazards master students: Anthoula Anagnostopoulou, Martin Calianno, Camille Lannes, Georgia Lysitsa, Paloma Mouillon, Savina Partheni, and Jimmy Zwiebel for their contribution to the data collection.

\section{REFERENCES}

Borga, M., E. Gaume, J.-D. Creutin, and L. Marchi, 2008: Surveying flash flood: Gauging the ungauged extremes. Hydrol. Processes, 22, 3883-3885. 
, E. N. Anagnostou, G. Blöschl, and J. D. Creutin, 2011: Flash flood forecasting, warning and risk management: The HYDRATE project. Environ. Sci. Policy, 14, 834-844.

CETE, cited 2011: Campagnes de relevés de PHE et de zones inondées. [Available online at http://cete-aix.fr/imgarea/ Campagnes\%20de\%20releves\%20de\%20PHE\%20et\%20de\% 20zones\%20inondees.pdf.]

Clark, A. F., and S. T. Doherty, 2010: A multi-instrumented approach to observing the activity rescheduling decision process. Transportation, 37, 165-181.

Creutin, J.-D., M. Borga, C. Lutoff, A. Scolobig, I. Ruin, and L. Creton-Cazanave, 2009: Catchment dynamics and social response during flash floods: The potential of radar rainfall monitoring for warning procedures. Meteor. Appl., 16, 115-125.

_ - E. Eruntfest, C. Lutoff, D. Zoccatelli, and I. Ruin, 2013 : A space and time framework for analyzing human anticipation of flash floods. J. Hydrol., 482, 14-24, doi:10.1016 j.jhydrol.2012.11.009.

Dash, N., and H. Gladwin, 2007: Evacuation decision making and behavioral responses: Individual and household. Nat. Hazards Rev., 8, 69-77.

Delrieu, G., and Coauthors, 2005: The catastrophic flash-flood event of 8-9 September 2002 in the Gard region, France: A first case study for the Cévennes-Vivarais Mediterranean Hydrometeorological Observatory. J. Hydrometeor., 6, 34-52.

Doherty, S. T., and E. J. Miller, 2000: A computerized household activity scheduling survey. Transportation, 27, 75-97.

Drabek, T., 1986: Human System Responses to Disaster: An Inventory of Sociological Findings. Springer-Verlag, 479 pp.

- 2000: The social factors that constrain human responses to flood warnings. Floods, D. Paker, Ed., Vol. 1, Routledge, $361-376$.

Drobot, S., and D. J. Parker, 2007: Advances and challenges in flash flood warnings. Environ. Hazards, 7, 173-178.

Gaume, E., and C. Bouvier, 2004: Analyse hydro-pluviométrique des crues du Gard et du Vidourle des 8 et 9 Septembre 2002. Houille Blanche, 6, 99-106.

— , and M. Borga, 2008: Post-flood field investigations in upland catchments after major flash floods: Proposal of a methodology and illustrations. J. Flood Risk Manage., 1, 175-189.

_ M. Livet, M. Desborbes, and J.-P. Villeneuve, 2004: Hydrological analysis of the River Aude, France, flash flood on 12 and 13 November 1999. J. Hydrol., 286, 135-154.

Goldman, M. J., P. Nadasdy, and M. D. Turner, Eds., 2011: Knowing Nature: Conversations at the Intersection of Political Ecology and Science Studies. University of Chicago Press, $376 \mathrm{pp}$.

Gruntfest, E., 1977: What people did during the Big Thompson flood. Natural Hazard Center Working Paper 32, $71 \mathrm{pp}$.

Holling, C., 2001: Understanding the complexity of economic, ecological, and social systems. Ecosystems, 4, 390-405.

Hornus, H., and X. Martin, 2005: Retour d'expérience sur la vigilance crue et son intégration dans le dispositif de crise lors des événements pluviaux du 6 au 9 Septembre 2005 dans le Gard et l'Hérault. Inspection Générale de l'Environnement Rep. IGE/05/056, $17 \mathrm{pp}$

Huet, P., X. Martin, J.-L. Prime, P. Foin, C. Laurain, and P. Cannard, 2003: Retour d'expérience des crues de Septembre 2002 dans les départements du Gard, de l'Hérault, du Vaucluse, des Bouches-du-Rhône, de l'Ardèche et de la Drôme. Inspection Générale de l'Environnement Rep. IGE/ 02/044, $133 \mathrm{pp}$.
Lefrou, C., X. Martin, J.-P. Labarthe, J. Varret, B. Mazière, R. Tordjeman, and R. Feunteun, 2000: Les crues des 12, 13 et 14 Novembre 1999 dans les départements de l'Aude, de l'Hérault, des Pyrénées-Orientales et du Tarn. Inspection Générale de l'Environnement Rep. 00/004, 146 pp.

Leonard, J.-L., 2010: Rapport d'information sur les raisons des de dégâts provoqués par la tempête Xynthia. Assemblée Nationale Tech. Rep. 2697, 141 pp.

Lindell, M. K., and R. W. Perry, 1992: Behavioral Foundations of Community Emergency Planning. Taylor and Francis, $630 \mathrm{pp}$.

—, and - Eds., 2004: Communicating Environmental Risk in Multiethnic Communities. Sage, 272 pp.

Liu, J., and Coauthors, 2007: Coupled human and natural systems. Ambio, 36, 639-649.

Martin, C., 2010: Les inondations du 15 Juin 2010 dans le centre Var: Réflexion sur un épisode exceptionnel. Études de Géographie Physique, Vol. 37, Physio-Geo, 41-76.

Mileti, D., 1995: Factors related to flood warning response. Proc. United States-Italy Research Workshop on the Hydrometeorology, Impacts, and Management of Extreme Floods, Perugia, Italy, National Science Foundation/Italian National Research Council, 4.6. [Available online at http://www.engr.colostate. edu/ jsalas/us-italy/papers/46mileti.pdf.]

Morss, R. E., O. V. Wilhelmi, G. A. Meehl, and L. Dilling, 2011: Improving societal outcomes of extreme weather in a changing climate: An integrated perspective. Annu. Rev. Environ. Resour., 36, 1-25.

Nuissier, O., V. Ducrocq, D. Ricard, C. Lebeaupin, and S. Anquetin, 2008: A numerical study of three catastrophic precipitating events over western Mediterranean region (southern France). Part I: Numerical framework and synoptic ingredients. Quart. J. Roy. Meteor. Soc., 134, 111-130.

Parker, D. J., and J. W. Handmer, 1998: The role of unofficial flood warning systems. J. Crisis Contingencies Manage., 6, 45-60.

_ - S. J. Priest, and S. M. Tapsell, 2009: Understanding and enhancing the public's behavioural response to flood warning information. Meteor. Appl., 16, 103-114.

Payrastre, O., and Coauthors, 2012: Hydrological analysis of the catastrophic flash flood of 15th June 2010 in the area of Draguignan (Var, France). Proc. Congrès SHF: Evènements Extrêmes Fluviaux et Maritimes, Paris, France, SHF.

Pitt, M., 2008: Learning lessons from the 2007 floods. The Pitt Review Tech. Rep., 505 pp.

Roorda, M., M. Lee-Gosselin, S. Doherty, E. Miller, and P. Rondier, 2005: Travel/activity panel surveys in the Toronto and Quebec City regions: Comparison of methods and preliminary results. Preprints, Second Int. Colloquium on the Behavioural Foundations of Integrated Land-Use and Transportation Models: Frameworks, Models and Applications, Toronto, Canada, University of Toronto, 1-37.

Rouzeau, M., X. Martin, and J.-C. Pauc, 2010: Retour d'expérience des inondations survenues dans le département du Var les 15 et 16 Juin 2010. Inspection Generale de l'Administration Rep. 10-070-02, 94 pp.

Ruin, I., 2010: Conduite à contre-courant et crues rapides, le conflit du quotidien et de l'exceptionnel. Ann. Georgr., 674, 419-432. , and C. Lutoff, 2004: Vulnérabilité face aux crues rapides et mobilités des populations en temps de crise. Houille Blanche, 6, 114-119.

_ J.-C. Gaillard, and C. Lutoff, 2007: How to get there? Assessing motorists' flash flood risk perception on daily itineraries. Environ. Hazards, 7, 235-244. 
- J.-D. Creutin, S. Anquetin, and C. Lutoff, 2008: Human exposure to flash floods-Relation between flood parameters and human vulnerability during a storm of September 2002 in southern France. J. Hydrol., 361, 199-213.

Sorensen, J. H., 2000: Hazard warning systems: Review of 20 years of progress. Nat. Hazards Rev., 1, 119-125.

Vinet, F., D. Lumbroso, S. Defossez, and L. Boissier, 2012: A comparative analysis of the loss of life during two recent floods in France: The sea surge caused by the storm Xynthia and the flash flood in Var. Nat. Hazards, 61, 1179-1201.

Walters, B. B., 2012: An event-based methodology for climate change and human-environment research. Geografisk Tidsskrift (Danish J. Geogr.), 112, 135-143.

- and A. P. Vayda, 2009: Event ecology, causal historical analysis, and human-environment research. Ann. Assoc. Amer. Geogr., 99, 534-553. 